\title{
Mentor as maestro - van mineur na majeur: Die rol van oordrag tussen mentor en mentee
}

\begin{abstract}
Author:
Johan $\mathrm{Nel}^{1}$

Affiliation:

${ }^{1}$ Department of Practical

Theology, University of the

Free State, South Africa

Correspondence to:

Johan Nel

Email:

jnel@ufs.ac.za

Postal address:

PO Box 28343, Danhoff 9310,

South Africa

Dates:

Received: 30 June 2011

Accepted: 10 Aug. 2011

Published: 04 Nov. 2011

How to cite this article: Nel, J., 2011, 'Mentor as maestro - van mineur na majeur: Die rol van oordrag tussen mentor en mentee', HTS Teologiese Studies/ Theological Studies 67(3), Art. \#1125, 8 pages. http:// dx.doi.org/10.4102/hts. v67i3.1125
\end{abstract}

Mentor as maestro - from minor to major: The role of transfer between mentor and mentee This article takes a glance at the role played by a mentor. The emphasis is on the authentic mentoring process. The metaphor of music is used to illustrate the different keys in which people experience life at large. The hypothesis poses that the transgression takes place during the interaction between the mentor and mentee. As in music, lives can be modulated into another, major key, which may lead to a life of abundance.

'This is the luxury of music ... I love it for what it makes me forget, and I love it for what it makes me remember'.

(Kennedy 2004:ii)

\section{Inleiding}

Geestelike mentorskap is wyd onder bespreking. In die meeste kerkgenootskappe is daar in mindere of meerdere mate ' $n$ mentorskapprogram in plek. Die doel hiermee is om vir predikante en teologiese studente die infrastruktuur te skep waarbinne hulle kan ontwikkel, werk en ondersteuning vind. Ook in die korporatiewe wêreld word mentorskap, leerlingskap en tutorskap een van die sterk pilare waarbinne persone onder die leiding van 'n ervare persoon onderrig en gevorm word. ' $n$ Mentor word onder meer beskou as ' $n$ raadgewer, tutor, studieleier, onderwyser en instrukteur (Pharos 5 in 1 Woordeboeke n.p.).

'n Sprekende voorbeeld van mentorskap kan in die boek van Alblom (1997), en nou ook rolprent Tuesdays with Morrie, gevind word. Die mentor, wat aanvanklik slegs die tutor was, het ' $n$ beduidende invloed op sy voormalige student. Sy lewensfilosofie daag sy student uit om nuwe horisonne te ontdek en 'n alternatiewe verhaal te ontsluit met die dekonstruksie van sy lewensnarratief (White 1992). So ook het die spraakterapeut, Lionel Logue, in die rolprent The King's Speech (2010) die rol van mentor eerder as tutor ingeneem. Die interessante binne hierdie konteks is dat die mentorskap 'n onbewustelike oordrag van waardes, norme en lewenskwaliteite is. Die mentor self is dus onbewus van die oordrag, en daar is niks doelbewus en beplan hieraan nie. Dit is derhalwe van alle kunsmatigheid gestroop. Die gees van die mentor spreek eenvoudig tot die gees van die student, met die resultaat dat die student veel meer verwerf as ' $n$ akademiese kwalifikasie of begeleiding binne ' $n$ sekere struktuur. Die student of mentee beleef ' $n$ proses van rypwording deur die inspeel van die mentor in sy lewe. As derde en laaste voorbeeld geld die karakters in die Afrikaanse rolprent Roepman (2011) (gebaseer op die boek deur Jan van Tonder in die laat 1990's). Twee uiterstes word hierin uitgebeeld: die verteenwoordigers van die tradisioneel Afrikaanse kerke van die 1960's in kontras met die eenvoudige, maar inspirerende geloof van die karakter, Joon, 'n roepman. Die roepman, wat 'n uiters nederige werk by die Spoorweë verrig, se geloof word deur sy oë wat altyd hemelwaarts gerig is, vergestalt. Hy is die een in die gemeenskap wat altyd die goeie en die regte doen. Die kerk, aan die ander kant, kyk af na, asook af óp die mense. Die roepman is egter die rolmodel. In sy eenvoud is hy die mentor vir die gemeenskap, en veral vir die jong seunskarakter Timus. Let op hoe Joon, anders as die kerk, nie met dogmas en leerstellings oortuig nie, maar met sy lewe: '... care not cure will keep us floating in the ocean' (Weingarten 2001:124).

\section{Die vraagstelling}

Binne die kerk bestaan die behoefte aan mentors op verskeie vlakke: eerstens in die aanvanklike akademiese vorming van studente aan tersiêre inrigtings. Die Kuratorium vir Teologiese Opleiding kan in 'n sekere deel van hierdie behoefte voorsien, maar die skrywer is daarvan oortuig dat daar veral ook buite formele strukture en toesighoudende liggame kosbare en onontbeerlike mentorskap kan plaasvind. Later, wanneer die predikant die bediening betree, bly die behoefte aan 'n mentor steeds 'n realiteit. Verskeie faktore dra hiertoe by, onder meer die gebrek aan vertroue onder kollegas (Greenfield 2003:104). Verskeie studies, soos dié van Nieman (2010), toon 
dat uitbranding selfs by teologiese studente voorkom, en die hoë uitbrandingsyfer onder predikante in die bediening is reeds veelbesproke. Die omvattende studies van Greenfield (2003) en Niemann (2010) toon dat die uitbrandingsyfer onder predikante so veel as $43 \%$ beslaan. Die welstand van die predikantekorps in die Nederduitsch Hervormde Kerk van Afrika (NHKA) wek in so 'n mate kommer, dat, tydens die Algemene Kerkvergadering in 2010 daar vir die eerste keer ' $n$ besluit geneem en fondse bewillig en geoormerk is ten behoewe van die welstand van predikantgesinne (NHKA 2010). Die besluit lui soos volg:

1. Die daarstel van 'n eenheidstruktuur binne die Kerk wat op 'n multiprofessionele basis dienswerk sal lewer ten opsigte van pastoriegesinne, word uitgevoer met die moontlikheid dat die dienswerk later uitgebrei kan word na ander teikengroepe en selfs vir ander instansies (byvoorbeeld Kerke) beskikbaar gestel kan word.

2. Die voorkomende en nasorgprogramme word ingestel en gebaseer op die beradingsprogramme se inligting soos vanuit die terapie bekom

(NHKA 2010:119)

Akademici is voortdurend besig met ' $n$ proses om leiding te bied, kennis oor te dra, bepaalde take af te handel ter begeleiding van die student wat ten doel het om ' $n$ akademiese mylpaal suksesvol te bereik of 'n kwalifikasie te verwerf. Die vraag ontstaan onwillekeurig: is dit die somtotaal van die dosent se rol in die kandidaat se lewe? Is daar nie, en behoort daar nie veel meer te wees as slegs die afhandeling van 'n voltooide akademiese module wat aan bepaalde akademiese vereistes voldoen nie? Hierdie artikel vra nuuskierig na die impak van die mentor self: is dit die oordrag van kennis, of die begeleiding om 'n bepaalde taak af te handel? Of impliseer dit ook 'n onbewuste krag wat van hom uitgaan, die oordrag van die kwaliteite van menswees? Het die studieleier in ' $n$ teologiese omgewing nie veel meer te bied as in die ander wetenskappe nie? 'n Onvermydelike vraag ontstaan ook: hét die mentor of rolmodel meer om te bied as slegs akademiese vaardigheid?

'n Verdere vraag wat ontstaan, is waarom 'n predikant aanklank vind by sekere kollegas, positiewe oordrag tussen twee individue plaasvind, terwyl dieselfde persoon by 'n ander geen aansluiting vind nie? Vir die doeleindes van hierdie artikel word gefokus op die 'rapport' tussen mentor en mentee as ruimte waarbinne die oordrag plaasvind. Hierdie oordrag moet ook verreken word binne die postmoderne samelewing waarbinne ons funksioneer. 'There are no absolute truths and no fixed values, because of the principle of difference' (Janse van Rensburg 2000:9). Binne hierdie vloeibare samelewewingskonteks is die invloed van 'n mentor dikwels die anker waaraan die mentee koppel, juis vanweë die gebrek aan vaste waardes.

\section{Metode}

Hierdie artikel werk verkennend met die konsep 'mentor'. Wanneer leeswerk oor die onderwerp gedoen word, is dit spoedig duidelik dat min navorsing, selfstandige en veral gesaghebbende uitsprake oor die onderwerp beskikbaar is. Hiermee word onmiddellik ' $n$ leemte in die teologiese veld geïdentifiseer en uitgelig. Verdere ondersoekende en volgehoue denke en navorsing is noodsaaklik.

Die uitgangspunt is dat daar nie ingrypende veranderings aangeleer word nie, maar:

... [is] not about making incremental changes that lead to new ways of doing things based on old beliefs, and they are not about self-improvement. They are geared instead toward causing a total shift of posture, perceptions, beliefs ... they are about transforming your entire world.

(Zander \& Zander 2002:4)

Ten einde die konsep van mentoroordrag te begryp, word musiek as metafoor gebruik om aan te toon hoedat menselewens voortdurend tussen uiterstes beweeg. Die maestro [dirigent, voorganger, mentor] se rol in die oordrag van meer as kennis - maar inderdaad ook om 'n spesifieke indruk op die persoon se lewe te maak - word uitgewys. Die metafoor wat gebruik word, is die Messias van G.F. Händel.

'n Insetsel van kwalitatiewe gesprekvoering met 'n klein aantal respondente, wys op ervarings wat tweërlei van aard kan wees: iets van die mentor het tot die wese van die kandidaat gespreek, terwyl die respondent ontnugter deur die kliniese opset van die leiding is.

\section{Die mentor}

Die akademiese verwagte uitkoms is duidelik: om die kandidaat te begelei om suksesvolle akademiese uitsette te lewer. Akademici verkeer toenemend onder druk om navorsingsuitsette deur hulself, sowel as uit die pen van hul studente, te lewer. Binne die bestaande mentorprogramme is die veronderstelde uitkoms ook duidelik: begeleiding tot rypwording, insig en 'n ryker lewe.

Weens die beperkte omvang van hierdie artikel, is dit nie moontlik om antwoorde op al die vrae te bied nie, maar die skrywer sal minstens poog om aan die hand van die musiekmetafoor verkennend te beweeg op die terrein van mentorskap. Verder sal beginsels van die narratiewe terapie (White 1992:21) ook geïntegreer word om tot 'n sinvolle geheel te kom.

\section{Begripsomskrywing}

Dit is nodig om ' $n$ onderskeid tussen die verskillende vorme van begeleiding te tref. Benamings wat gebruik word vir persone wat in ander se lewens 'n beduidende rol speel, sluit in tutor, lewensafrigter ('life coach'), mentor, motiveerder, protégé, rolmodel, en ander. Dit is egter belangrik om deurgaans te onthou dat die mentorskap hier ter sprake, juis nié 'n terapeutiese ingreep is nie. Linström (2009) maak juis 'n sterk saak daarvoor uit dat die Pastorale Terapeut of mentor nie 'n kwasi-sielkundige behoort te wees nie. Dit is veel eerder 'n begeleidingsproses waarbinne sekere stelle inligting uitgeruil word. Die gees waarbinne dit gebeur, is egter van besondere belang. 
Aangesien hier van die narratiewe benadering uitgegaan word, is dit belangrik om kennis te neem van die feit dat slegs postmoderne terme binne hierdie konteks bruikbaar kan wees. 'n Tutor is byvoorbeeld iemand wat doelbewuste onderrig gee, sodat sekere beginsels en kennis oorgedra kan word, terwyl die lewensafrigter ook die deskundige is wat binne die proses beheer neem. 'n Motiveerder gaan op 'n eksakte wyse met die persoon wat onder sy vlerk geneem word, om. Die term 'sielkundige' veronderstel 'n sekere kennis en gesag op 'n bepaalde gebied wat ook vir die terme 'berader' en 'terapeut' geld. Al hierdie benamings word binne die modernistiese diskoerse gevind. In die narratief, word die terapeut egter nie as die kundige beskou nie, maar wel as die kliënt. Die filosofie is dat elkeen meester van sy of haar eie verhaal is.

Hierdie beginsel dui op die kulminasie van wat bereik wil word, naamlik dat die mentor met respek teenoor die mentee die ruimte sal laat vir nuwe ontdekkings, nuwe moontlikhede en dus 'n alternatiewe verhaal (White 1992, 1997, 2007). Aangesien die mentor 'n nie-wetende posisie inneem, bestaan die ruimte en vryheid sodat die mentee self 'n alternatiewe lewensverhaal kan ontdek.

Om te bepaal wat die rol van die mentor is, is dit miskien nodig om duidelik te omskryf wat die mentor nie is nie. Eerstens is die mentor nie 'n oordraer van kennis nie. Die mentor 'leer' nie die mentee sekere beginsels of stappe tot sukses nie. Die kruks is juis hierin geleë: die mentor se eie menswees is kongruent aan sy waardes en is geloofwaardig. Egtheid sonder pretensie is onderliggend, maar vorm die goue draad, sodat die mentee nie eens doelbewus kan verwoord wat hy of sy ervaar nie. Kortom sou dit daarop neerkom dat hy of sy sal verklaar: 'ek wil soos hierdie persoon wees'; 'hierdie persoon se lewe het snydend in my lewe ingewerk, ek moduleer op die mentor, en kan nie anders nie.' Zander en Zander (2002) werk deurgaans met die konsep van moontlikhede wat oopgaan en deur die interaksie self ontdek word.

\section{Die metafoor: Musiek Musiek binne die narratief}

In die narratiewe terapie word daar met die verhale van mense omgegaan. Sommige individue se verhale word gekenmerk deur groot suksesse en indrukwekkende prestasies. Ander mense se verhale word deur trauma, pyn en verwonding gekenmerk. Die vraag ontstaan onmiddellik of die eersgenoemde werklik aan minder emosionele en fisiese uitdagings as die verwonde onderwerp is. Indien wel, sou die pyn van die verlede reeds geïntegreer wees, sodat die individu die heil van hoop (Louw 2005:51) ervaar? Daar word dikwels verkeerdelik aannames oor mense gemaak. Enersyds kan daar aangeneem word dat sommige mense dit (skynbaar) 'maklik' het, terwyl ander weer die een teëspoed na die ander beleef. Alle mense se lewens bestaan egter uit verskillende getye. Dit sal mettertyd vanuit die metafoor van 'n musiekkomposisie (Messias van G.F. Händel) duidelik word dat die getye beskryf word in terme van verskillende toonaarde, tempo's en ritmes in die gang van elke dag.
Die literatuur ondersteun die stelling dat alle mense in 'n mindere of meerdere mate onder verwonding gebuk gaan. Hierdie verwonde daag by die tersiêre instelling op in die hoop om op akademiese gebied sukses te bereik. Verwonde mense betree die bediening met die hoop dat hulle binne die vervulling van, en in liefdesgemeenskap, oplossings vir hulle pyn sal kry (Greenfield 2003:13). Onvermydelik moet kennis geneem word van die feit dat die mentor ook onder verwondheid gebuk gaan. Greenfield (2003:13) meld hoe hy ontnugter is: 'Looking back, I must admit that I was somewhat naive about how conflict and division take place in the church.' Intussen ervaar beide mentor en mentee dikwels dat ' $n$ verandering in toonaard in hulle lewens plaasvind. In musiekterme word van modulasie gepraat wanneer na die verandering in toonaard verwys word. Dit is egter hierdie eie verwondheid van die mentor wat van hom maak wie hy is: die maestro. Nie net beskik hy oor die akademiese vaardigheid nie, maar is hy ook 'n Geesvervulde Christen wat lewenservaring na alle kante het.

Die lewensnarratief (komposisie) van elke mens, beide dié van die mentor en die mentee, bestaan onafhanklik van mekaar uit verskillende bewegings. Dit sluit in gelykmatige tye (ruhich) wat ander kere in stroomversnellings (accelerando) kan verander. Dikwels is dit noodsaaklik om die pas stadiger te neem (ritardando), en ander kere keer dit weer terug na die 'normale' tyd (a tempo). Seisoene van die lewe word in verskillende toonaarde beleef. Soms is die aard mineur (hartseer), ander kere majeur (positief, uitbundig).

\section{Gevoel en emosie in musiek}

Stemming en gevoel word in musiek deur verskeie elemente bewerk. Verskillende toonaarde, tempo en ritme is voorbeelde van hoe emosie in musiek vertolk kan word.

Om tot ' $n$ beter begrip te kom van hoe die metafoor binne die lewensnarratief aangewend word, word 'n kort beskrywing van die twee toonaarde ter sprake gegee. Musiektoonlere is afkomstig van die Latynse woord scala wat 'trappe' beteken. 'n Reeks enkele note volg mekaar trapsgewys opwaarts en afwaarts. Majeur- en mineurtoonaarde word diatoniese toonlere genoem (Kennedy 2004:639). 'n Majeur is dus 'n diatoniese toonleer waarbinne die intervalle telkens een toon bevat. Die majeursleutel is die sleutel wat gebaseer is op die toonleer, genoem die majeurakkoord. Hierteenoor het die mineurtoonaard 'n sogenaamde 'relatiewe' majeurtoonaard wat op drie halftone bo die majeur dominant voorkom. Die mineurakkoord word so gevorm. Vir die doeleindes van hierdie artikel word die tegniese aspekte van die teorie onderliggend aan musiek nie verder bespreek nie, maar slegs aangehaal om by die klank (stemming) van elkeen te kom.

In leketaal kan 'n oorvereenvoudiging hiervan, waarin gesuggereer word dat die majeurtoonaard 'n sterk, positiewe klank voortbring, gebruik word. Die mineur-toonaard aan die ander kant, klink op die oor hartseer en ingetoë, selfs melankolies. Ter versterking hiervan: Lofliedere word gewoonlik in 'n majeur geskryf, terwyl die Lydensliedere 
byvoorbeeld weer mineurklanke voortbring, wat die terughoudende hartseerklank verteenwoordig. Wanneer die Messias van Händel ter illustrasie gebruik word, is dit opmerklik hoe daar van majeur- na mineurtoonaarde binne die komposisie verwissel word. Die stemming van die betrokke deel van Christus se lewe word hierdeur as't ware as 'n toonaard uitgedruk. 'n Stewige tempo dui gewoonlik op uitbundigheid, terwyl die mineur in musiek of menselewens teen 'n gestadigde tempo vertolk word. Dieselfde geld ritmiese dinamika binne musiek. In die Messias word hierdie momente baie sterk deur bogenoemde faktore ondersteun.

\section{Die Messias (G.F. Händel)}

In 1741 is die beroemde Messias binne drie weke deur die komponis, G.F. Händel, gekomponeer (Ainsley 1995:212). Hoewel Händel grootliks as 'n teatrale komponis beskou is, word met hierdie komposisie' $n$ beduidende en onuitwisbare toevoeging tot kerkmusiek gemaak.

Waarom juis Händel? Dit wil voorkom of Händel self ook 'n mentor was, met spesifieke verwysing van sy outentieke lewenswyse. Händel was bekend as 'n weldoener, sonder voorbehoud en sonder aansiens des persoons. Groot dele uit die opbrengste van die Messias is aangewend om mense se lewensomstandighede te verbeter. En tog was hy soos sy tydgenote, ook nie altyd ewe suksesvol nie (Baker 1990:159).

Die hipotese dat daar in die leeftyd van elke mens herhaaldelik majeur- en mineurbewegings voorkom, word by wyse van vergelyking, soos die 'bewegings' in Jesus se lewe, met elke mens se lewe geïntegreer. Terwyl Händel die Messias gekomponeer het, was hy op 'n persoonlike laagtepunt in sy lewe - 'n mineur by wyse van spreke. Sy lewenstempo was 'stadig' as gevolg van sy gemoedstoestand. Hy was brandarm, en sy gesondheid het 'n knou gekry weens wanvoeding. Te midde van hierdie 'mineur'-seisoen in sy lewe begin hy die Messias komponeer wat binne 24 dae afgehandel is. Daar is ook geen twyfel dat hierdie tydperk van sy lewe gekenmerk is deur'n spirituele verdieping en besinning nie. Tog vind die modulasie plaas. 'n Weldoener wat tydens die komposisie van die Messias vir hom kos gebring het, sou na bewering meld dat hy Handel, na voltooiing van die 'Halleluja'-koor, hoor uitroep het: 'I did think I did see all Heaven before me, and the great God himself!' (Ainsley 1990:193).

Die drie bewegings in die Messias toon wat musiek sowel as teks betref ooreenkomste met sy eie lewensnarratief, uitgebeeld in die narratief van Jesus. Hierdie drie bewegings toon ook sterk ooreenkomste in elke mens se lewensnarratief: 'The three parts of this oratorio tell the events of Jesus' life and death' (Baker 1990:228). Die basiese struktuur van die komposisie bevat drie dele: die geboorte, die kruisiging en die opstanding, met die hoop op die ewige lewe:

[this] is robust enough to withstand all kinds of tinkering. The level of inspiration is amazing, from the overture through to the great fugal Amen Chorus. However overexposed it may be, it is a work of inexhaustible vitality and inventiveness.

(Ainsley 1995:212)
Juis omdat vitaliteit hoop suggereer, word die metafoor in hierdie artikel as hulpmiddel gebruik.

\section{Die drie bewegings binne die Messias as narratief}

Die Messias bestaan uit drie dele: die geboorte van Jesus, die lyding en sterwe, en die opstanding wat uitloop op die ewige lewe. Dit is in wese ' $n$ vertelling van die verhaal van die mens, Jesus. Binne hierdie lewensnarratief leef die mens Jesus van geboorte tot dood, asook in die lewe na die dood.

In die eerste deel word hoop gebring te midde van' $n$ hooplose situasie. Die volk se lewe sou in musiekterme beskryf kan word as 'n mineur-gedomineerde stadige gang as gevolg van die omstandighede. Dan kondig die profeet Jesaja die koms van die Messias aan. Enkele aanhalings uit die teks volg:

Sinfonia

Comfort ye, comfort ye My people,

Saith your God.

Speak ye comfortably to Jerusalem,

and cry unto her, that her warfare is accomplished

that her iniquity is pardoned.

The voice of him that crieth in the wilderness;

prepare ye the way of the Lord;

make straight in the desert a highway

for our God.

(Ainsley 1995:315)

Verskeie koorgedeeltes en arias verklank op feestelike wyse die koms van die Verlosser - die mineur-bestaan is aan die verbygaan. Teksgedeeltes uit die boek van die Profeet Jesaja, aangevul uit die Matteusevangelie, versterk die beloftes, en begelei die hoorder deur tempo en ritme om na 'n majeurtoonaard te moduleer.

In die tweede deel word die aandag gevestig op die Lam van God wat die wêreldsonde dra. Die ritme en tempo neem merkbaar af. Die duisternis van die kruisweg en Golgota word afgewag:

Behold the Lamb of God, that taketh

Away the sins of the world.

He was despised and rejected of men

A man of sorrows and acquainted with grief ...

Surely He hath borne our griefs ...

All we like sheep have gone astray, we have turned every one to his own way and the Lord hath laid on Him the iniquity of us all.

Behold, and see if there is any sorrow

Like unto His sorrow.

(Ainsley 1995:317)

Die tweede deel sluit af met die bekende 'Halleluja'-koor, waar die stemming verander na 'n algemene - 'n crescendo na 'n uitbundige en feestelike klimaks. Die majeurtoonaard kom hier tot sy volle reg. Die derde deel getuig met oorgawe van die Opstanding. Oorwinning as tema figureer sterk:

I know that my Redeemer liveth, and that he shall stand at the latter day upon the earth, and though worms destroy this body yet in my flesh shall I see God.

(Ainsley 1995:318) 
In die voorlaaste koorgedeelte word uitgejubel:

Worthy is the Lamb that what slain,

And hath redeemed us to God by His blood,

To receive power, and riches, and wisdom, and

Strength, and honour, glory and power,

Blessing and honour, glory and power, be

Unto Him that sitteth upon the throne, and

Unto the the Lamb, for ever and ever.

(Ainsley 1995:320)

Hierdie slotkoor loop uit op 'n oorwinnende crescendo, met 'n sterk ritmiese inslag waar klem op elkeen van die eienskappe geplaas word. Die tempo is sterk, stewig en ondersteunend.

\section{Verskillende toonaarde}

Binne die komposisie van Händel word verskillende toonaarde wat mekaar afwissel, aangetref. In die Messias vertolk die majeure die uitbundigheid en blydskap van die herders en die engelesang. Dit moduleer na ' $n$ mineur met die Lyding wanneer die Man van Smarte se lewenslig al hoe flouer skyn, en hy uiteindelik aan die kruis uitdoof. Wanneer Hy die dood oorwin, bars 'n Halleluja los - 'n majeur.

Louw (2005:4) maak melding van die intrinsieke behoefte om onvoorwaardelike aanvaarding by elke persoon. Hierdie aanvaarding kan in die voetspore van die Man van Smarte gevind word.

Die kuns van die lewe gaan om verstaan, insig, verantwoordelikheid en singewing. In hierdie proses is die een groot vraag, die vraag na geborgenheid en sekuriteit. Hierdie vraag kan ook anders gestel word: die vraag na intimiteit. Daarmee word bedoel die soeke na iemand of ' $n$ plek waar mens onvoorwaardelik aanvaar sal word vir wie jy is sonder die angs vir verwerping, isolasie en onregverdige diskriminasie; sonder die vrees dat jy op jou skuld en foute vasgepen sal word. 'Êrens soek mense 'n leefruimte waar liefde konkreet beteken: versoening, vergifnis en genade' (Louw 2005:4)

In die metafoor van die Messias ontplooi dié intieme ruimte op so 'n wyse dat elkeen daarbinne veilig kan voel.

\section{Die lewensnarratief van Christus en dié van elke mens}

Geen mens se lyding op aarde kan ooit vergelyk word met die lyding van Christus nie. En tog is daar binne Christus se lyding ruimte vir assosiasie met mense se lyding. Christus se lewe verklank 'n solidariteit met mense se lewens. Die Man van Smarte verstaan die lyding. Hy het dit tot die uiterste beleef. Daarom kan die mens in lyding sy lewensnarratief, te midde van die ontreddering, steeds beleef in die wete dat Iemand verstaan. Die hoop is geleë in die oorwinning uit die dood, en die ewige lewe.

\section{Die beginsels van die narratief}

Die baanbrekers in die wêreld van die narratiewe terapie, is Michael White en David Epston in die laat sewentigerjare van die vorige eeu. Hulle terapie word wêreldwyd met groot vrug, veral in huweliks- en gesinsterapie, aangewend. Daar is ook ander betekenisvolle bydraers in die veld van die narratiewe terapie, maar vir die doel van hierdie diskoers word volstaan by die beginsels soos deur White en Epston (1990) uiteengesit.

\section{Die filosofie van die narratiewe denke}

Met hulle boek, Narrative means to therapeutic ends (1990), betree White en Epston die veld van die post-modernisme (Parry \& Doan 1994:18). Bateson, Foucault en Geertze (in Parry \& Doan 1994) het 'n groot invloed op die werk van White en Epston uitgeoefen. Die belang van hierdie navorsers vir die doel van hierdie artikel, lê daarin dat hulle die narratief van die terapeut, in hierdie geval die mentor, deeglik verreken. Die mentor se lewe bestaan ook uit ' $n$ bepaalde narratief wat in verskillende toonaarde uitgespeel word.

White opponeer die vraag van die strukturalisme na die 'waarheid', deur 'n ander vraag te vra, naamlik 'wat of wie is ons vandag?'. In die lewe van Christus was daar baie waarheidsoomblikke, maar die klem word na die ander vrae verskuif: 'Wie of wat het Hy geword? Wie of wat is ons in lyding? Waartoe word ons gebring in lyding?' Hierdie vrae is relevant in dié opsig dat dit die wesensvrae is wanneer na die narratief van die mentor gekyk word, en veral dan wanneer hy vanuit sy lewensnarratief onbewustelike oordrag op die mentee doen. Soos White dit stel: ' $\ldots$ all knowing requires an act of interpretation' (White \& Epston 1990:2).

Drie beginsels: Eksternalisering van die probleem, die gebruik van taal en betekenis, en dekonstruksie

In aansluiting by Prinsloo (2011:1) word die beginsels van eksternalisering, taal en dekonstruksie kortliks verduidelik. Dit sal dan lig werp op Jesus se lewensnarratief, soos gedekonstrueer deur Händel in die Messias, met eksternalisering van die dinge wat noodwendige modulering vanaf die majeur na 'n mineur en weer terug na 'n uitbundige majeur met die oorwinning uit die dood, impliseer.

Eksternalisering is die proses waarin persone tydens terapie die probleem objektiveer. Freedman en Combs (1996:47) stel dit soos volg: 'The person is not the problem, the problem is the problem.' Ook binne die teorie van die narratief funksioneer die 'uithaal' van die probleem, oftewel die eksternalisering daarvan, baie sterk. Die persoon raak nou bewus, nie net van die probleem nie, maar ook van sy verhouding met die probleem:

This takes them out of a fixed and static world, a world of problems that is intrinsic to persons and relationships, and into a world of experience, a world of flux. In this world persons find new possibilities for affirmative action, new opportunitiesto act flexibly.

(White \& Epston 1990:42)

Christus se lewensnarratief word deur die Messias weergegee, maar dit is veel meer as 'n vertelling. Eksternalisering vind plaas waar insidente en gebeure nie staties en enkelvoudig voorkom nie. Die teenoorgestelde vind plaas. Lyding en vreugde wat vloeibaar is, maak deel uit van hierdie merkwaardige lewensnarratief. Deur middel 
van eksternalisering kan verskeie betekenisvolle 'probleme' van sy lewe uitgewys word. Noodwendig volg dan die verhouding wat Jesus met die probleem gehad het en wat uitloop op die noodwendige modaliteit: 'wie is Hy nou?'

Ten opsigte van taal en betekenis, vind oordrag op verskeie maniere en op verskillende vlakke plaas. Anderson en Goolishan (1992) wys daarop dat kennis binne die narratief in taal oorgedra word, deur middel van dialoog waar dit sosiaal gekonstrueer word. Prinsloo (2011:16) stel dit duidelik dat menslike sisteme 'taal-genererende' en 'betekenisgenererende' sisteme is. Betekenis en verstaan word sosiaal gekonstrueer: 'Twee of meer persone stem saam dat hulle dieselfde gebeure op dieselfde manier beleef en verstaan' (Prinsloo 2011:16).

Anderson en Goolishan (1992:3) beklemtoon dat die terapeut vanuit 'n posisie van 'nie weet nie' met die persoon in dialoog tree. Die terapeut beskou sigself nie as die kenner van die lewe van die kliënt nie, maar eerder as 'n nuuskierige reisgenoot wat tot 'n beter verstaan wil kom. Händel funksioneer in sy Messias as die reisgenoot wat nie weet nie, maar wel reflekteer. Die resultaat is effens anders as wat in die narratiewe terapie gevind word: die (P)persoon ontdek nie die waarhede hier nie, maar wel die leser of hoorder.

Die Franse filosoof Derrida, het die term 'dekonstruksie' die eerste keer gebruik. White (1992) se beskrywing van die term is soos volg:

... deconstruction has to do with procedures that subvert takenfor-granted realities and practises of self and of relationships that are subjugating of person' lives. Manyof the methods of deconstruction estrange these familiar and everyday taken-forgranted realities and practices by objectifying them.

(White 1992:121)

Om te dekonstrueer, beteken om as't ware die knope van 'n verhaal te ontknoop, los te wikkel, en uitmekaar te haal. Daar moet nuuskierig nagegaan word wat die betekenis is wat die persoon aan elke onderdeel gee. Dit help die persoon om betekenis daaraan te heg, en dit help die terapeut (mentor) om te verstaan. Verborge betekenisse word so betekenisvol uitgelig. Kulturele en sosiale raamwerke en die verstaan daarvan, is hier noodsaaklik (Prinsloo 2011:19). Om die Christusverhaal te verstaan, is dit noodsaaklik dat dekonstruksie plaasvind. Die Messias funksioneer as veel meer as slegs 'n vertelling wat deur musiek ondersteun word. Die hoorder word saamgeneem op 'n reis waarin die lewe van Jesus gedekonstrueer word. Die dekonstruksie is noodsaaklik vir 'n verstaan van die Persoon van Jesus, maar eweneens ook vir die leser daarvan. Weer word beklemtoon dat die Christus-narratief in solidariteit met die mens in nood afspeel.

\section{Van C(hristus)-mineur na C(hristus)- majeur}

Wanneer dit blyk dat die individu se lewenstoonaard oorwegend in ' $\mathrm{n}$ mineur uitspeel, is die uitdaging om 'n proses van kentering te ondergaan sodat die lewe in volheid beleef kan word, in ' $n$ majeur. Dit is onder meer die doel van die pastorale terapie. Vanuit ' $n$ dun beskrywing word die potensiaal om na 'n majeur te moduleer, deur middel van begeleiding, na vore gebring. Dit behels groei vanuit 'n vasgeloopte, dun situasie na 'n sogenaamde dik beskrywing 'n lewensnarratief met unieke uitkomste wat voorheen nie waargeneem kon word nie. Die aard van die mineur was te dominant.

In hierdie metafoor staan Christus sentraal, vandaar die aanwending van die C-sleutel (Lees: Christus-sleutel). Ook as Christene beleef individue bepaalde mineure, wat deel van elkeen se realiteit is. Dat die hartseer kan oorgaan in 'n oorvloed-majeurlewe word deur hierdie modulasie teweeggebring. Die implikasie is nie dat daar nooit weer mineure sal voorkom nie, maar die unieke uitkoms, die identiteit in Christus, bepaal dat die majeur nou die dominante verhaal word. Uit hierdie oorwinningsperspektief kan die musiekleestekens in die lewens-bladmusiek nou draaglik word.

'n Lewensimfonie bevat inderdaad verskillende bewegings. Daar is byvoorbeeld rustekens in die musiek. Hierdie oomblikke van rus moet gerespekteer word, want die Komponis het dit immers met 'n doel aangebring. Die decrescendo's (wegsterf-) momente, sowel as die crescendo's (geleidelik harder tot 'n klimaks), die piano's (sagter), sowel as die fortes (harder, lewendiger) bepaal die dinamiek van die komposisie. Elke beweging moet sy verloop neem. So het die Komponis dit bedoel. Die oorwinning van Christus, soos verwoord en verklank in die beroemde 'Halleluja'-koor van die Messias, word nou die lewenstema van die individu, die lewenstoonaard. Selfs binne die verskrikking van die gebroke wêreld leef Christene te midde van mineur-insidente 'n majeurlewe.

\section{Die onbewuste modulator}

'n Baie belangrike aspek in die verhouding tussen mentor en mentee, is die feit dat ' $n$ ware mentor nie daarvan bewus is dat hy hierdie belangrike impak op die kandidaat het nie. Roepman se karakter Joon, Tuesdays se Morrie en die spraakterapeut van The Kings' Speech is eenvoudig wie hulle is. Hulle is hulle outentieke self. Dit kom spontaan na vore, dit 'gebeur net'. Daar is geen tegnieke waarmee die modulator onderrig kan word nie en geen skoling vind plaas nie. Opleiding wat die aanleer van tegnieke behels, sou 'n kunsmatigheid impliseer.

Wat wel 'n beduidende rol kan speel, is die vlak van geestelike en emosionele volwassenheid van die mentor. Hy is binne die akademiese omgewing die maestro. Sy eie oortuigings en sy definisie as persoon van integriteit, onderskei hom, en hy fasiliteer meer as slegs ' $n$ akademiese proses, is meer as net 'n gewillige oor waar 'n oorwerkte kollega kan ontlaai. Die mentee se verhaal word verryk en versterk om uit te loop op 'n slotakkoord, 'n kadens (oplossing). 


\section{Kan 'n mentor 'gekweek' word?}

Die behoefte aan mentors wat betekenisvol inspeel en lewensveranderende gedrag en alternatiewe hanterings- en oorlewingstrategieë uitdaag, kan nie oorbeklemtoon word nie. Die vraag is nou: Is dit moontlik om 'n mentor op te lei? Is daar êrens ' $n$ handleiding beskikbaar waar die mentor kan gaan leer hoe om te werk te gaan om die mentee se lewe te stuur om vanuit die mineur na 'n majeur oor te gaan, en 'n oorvloedslewe te lei? Of kan sodanige riglyne saamgestel word vir gebruik in mentorskapprogramme?

Voordat enige uitsprake hieroor gewaag word, moet in kort van 'n kwalitatiewe houdingsgesprek van 'n aantal individue binne die bediening kennis geneem word. Elkeen het kortliks hulle mening oor die kwessie van mentorskap gegee. Al die respondente is tussen 15 en 25 jaar in die bediening. Die steekproef is ewekansig, ongestruktureerd, maar wil geensins aanspraak maak op volledigheid of wetenskaplikheid nie. Wat hieruit na vore gekom het, kan hoogstens as persepsies (of sieninge) van individue beskou word. 'n Deeglike studie hieroor sou wenslik wees.

\section{Enkele gesprekspunte}

Agt respondente is in onafhanklike gesprekke oor die rol wat ander persone in hulle lewens en vorming gespeel het, gepols. Vier van die respondente het nagraads tot op magistervlak gevorder, terwyl een gepromoveer het. Die respondente is almal in die voltydse bediening in een van die tradisioneel Afrikaanse susterskerke. Die reaksie het soveel ooreenkomste getoon dat 'n gedetailleerde ontleding daarvan onnodig is.

Op 'n vraag oor hoe elkeen hulle lewe sou beskryf in terme van die musiekmetafoor van 'n majeur- of 'n mineurtoonaard, het slegs twee geantwoord dat hulle oor die algemeen meer vreugde as hartseer, spyt en ontnugtering beleef. Die waarneming is wel gemaak dat die vyf respondente wat oor nagraadse kwalifikasies beskik, 'n verhoogde vlak van selfaktualisering het. Hulle het rapporteer dat hulle gemotiveerd is om hulle steeds verder te bekwaam, nie met die noodwendigheid van 'n alternatiewe loopbaan nie, maar wel om hulleself beter te leer verstaan. Vier van die vyf het wel aangetoon dat, indien die geleentheid van 'n alternatiewe loopbaan hom sou voordoen, hulle dit ernstig sou oorweeg om die bediening te verlaat.

In sewe van die agt gesprekke met respondente is gerapporteer dat hulle huweliks- en gesinslewe baie ruimte vir verryking toelaat. Daar was selfs suggesties dat die huwelike 'n formaliteit is, met geen inhoud. Slegs een respondent het gerapporteer dat sy huwelik meer as bevredigend was.

Op die vraag na die invloed van 'n mentor(s) op hulle menswees tydens hul opleiding, het vyf uit die agt gemeld dat daar wel persone in hulle lewens ingespeel het (of dit steeds doen), deur wie hulle verryk is, en wat hulle as rolmodelle sou beskou. Die oorkoepelende hiervan is dat hierdie sogenaamde rolmodelle se menswees, en nie soseer hulle handelinge nie, die deurslag gegee het. Op 'n vraag aan wie die mentor hulle laat dink het, was die reaksies soos volg:

- Die mentor is soos Jesus

- Hy is vir my 'n Paulus (en ek Timoteus)

Woorde wat gebruik is, was onder meer: 'integriteit', 'gemaklik', 'oop', 'beginselvas', 'betroubaar', 'iemand by wie my geheime veilig is', 'opreg', 'opregte belangstelling', 'diep', 'kongruent', 'nie 'n speel-speel Christen nie'. 'n Opmerking wat opgeval het, was: 'Ek wens ek kon ook so wees.'

'Contextual theology has to remain provisional hypothetical with continuous dialogue taking place between text and context' (Bosch 1991:439). Die behoefte aan voortdurende interaktiewe dialoog - nie noodwendig verbaal nie - tussen mentor en mentee vorm ' $n$ belangrike bestanddeel van die oordragproses.

Al die respondente was daaroor uitgesproke dat die mentor na hulle mening onbewus was van die oordrag wat plaasvind, omdat 'nederigheid' een van die kenmerke was. Nog 'n opmerking het getref: 'Ek wens daar was meer sulke mense.' 'n Onverwagse opmerking was: 'die persoon het kort-kort erkenning aan my gegee en gesê hy leer baie by my.' (Let wel: die mentor wat by die mentee leer.)

Hoe moet die mentor dan wees? Indien die stelling waar is dat 'n mentor nie deur middel van 'n handleiding kan leer hoe om 'n rolmodel te wees nie, beteken dit dat daar slegs ' $n$ beperkte aantal mentors op aarde rondloop wat inderdaad as maestro's modulasie in persone kan teweegbring? Die opmerkings van die respondente wat aan die gesprekke deelgeneem het, is rigtinggewend: die mentor leef wie hy is. Daar is kongruensie, erns en diepte. Die outeur se oortuiging is dat meer natuurlike mentors na vore kan kom, indien hulle uit hulle outentieke self begin leef. White (1997:33) werk in hierdie verband met metafore soos solidariteit, alliansie, medewerking en affiliasie.

Verder is dit die skrywer se oortuiging dat, indien elke persoon bewus gemaak word van die feit dat hy (onbewustelik) 'n indruk op ander se lewens maak, dit daartoe sal lei dat mentorskap 'n vaste staanplek kan kry. Dit is ook belangrik om te besef dat dit veral in die mineur-bewegings van die mentor se eie lewe sigbaar word wie hy ten diepste is. 'n Mentor wat self deur 'n louteringsproses beweeg het, beskik oor ' $n$ rypheid van gees wat op sigself oortuiging inisieer. Hierdie mentor is reeds bekend met die innerlike dialoog wat binne elke mens, ook homself, plaasvind (Anderson 1991:40).

\section{Gevolgtrekking en samevatting}

Uit bogenoemde opmerkings met die ondersteuning van die metafoor, word die afleiding gemaak dat 'n groot behoefte bestaan aan persone wat kongruent aan hulle oortuigings leef. Sodanige persone, sulke mentors, dra daadwerklik tot die vaslegging van waardes in die persone van toekomstige mentors by. Die mentor is slegs ' $n$ reisgenoot op die pad wat 
deur die skep van 'n refleksiewe selfbewustheid die proses van nuwe uitkomste inisieer (Prinsloo 2011:23).

In wese kom dit daarop neer dat, anders as met studieleiding, terapie of lewensafrigting, dat die vertrekpunt tussen mentor en mentee 'n spontane, ongedefinieerde proses is. Die vertrekpunt is nie soos by terapeutiese ingrepe dat die geïdentifiseerde probleem die fokuspunt is nie, maar die positiewe kragte binne die individu. Daarvandaan word vertrek: 'And with that, she sailed into a universe of possibility' (Zander \& Zander 2002:1).

\section{Erkenning}

Theuns Dreyer het deur'n omvangryke akademiese loopbaan 'n onuitwisbare bydrae tot die akademiese en kerklike debat in Suid-Afrika gelewer. Prominente kerkleiding en sy betrokkenheid by die vorming van Dienaars van die Woord is sy tweede natuur. In my eie en baie ander se lewens, was en is hy as onbewuste mentor die instrument wat talle mineure na majeure moduleer.

\section{Mededingende belange}

Die outeur verklaar dat hy geen finansiële of persoonlike verbintenis het met enige party wat hom nadelig kon beïnvloed in die skryf van hierdie artikel.

\section{Literatuurverwysings}

Ainsley, R., 1995, The ultimate encyclopaedia of Classical music, Carlton Books Limited, Cape Town.

Alblom, M., 1997, Tuesdays with Morrie, Random Publishers, New York, NY.
Anderson, H. \& Goolishan, H., 1992, 'The client is the expert: A not-knowing approach to therapy', in S. McNamee \& K.J. Gergen (ed.), Therapy as social construction, pp. 25-39, Sage Press, London.

Baker, R., 1990, The Hamlyn illustrated encyclopaedia of Music, 2nd edn., The Hamlyn Publishing Group, London.

Bosch, D.J., 1991, Transforming mission: Paradigm shifts in theology of mission, Orbis Books, New York, NY.

Die Roepman, 2011, rolprent, Ster-Kinekor, Suid-Afrika.

Freedman, J. \& Combs, G., 1996, Narrative therapy: The social construction of preferred realities, WW Norton \& Company, New York, NY.

Greenfield, G., 2003, The wounded minister, Baker Books, Grand Rapids, MI.

Hendriks, H.J., 2004, Studying Congregations in Africa, 1st edn., Lux Verbi, BM, Wellington.

Kennedy, M., 2004, Oxford concise dictionary of music, Oxford University Press, New York, NY.

Linström, A., 2009, 'Het Pastorale Terapeute Kwasie-sielkundiges geword? 'n Pastorale studie', ongepubliseerde MA-verhandeling, Departement Praktiese Teologie, Universiteit van die Vrystaat.

Louw, D., 2005, Ratwerke van die menslike siel: Oor volwassenheid en lewensvaardighede, Sun Press, Stellenbosch.

Nieman, G.J., 2010, Die persepsies en belewenis van uitbranding by nagraadse teologiese studente van die Gereformeerde Kerke in Suid-Afrika - 'n Pastorale Studie, PU cir CHO, Potchefstroom. (Skripsie - MTh).

NHKA, 2010, Notule van die 69ste Algemene Kerkvergadering, NHKA, Pretoria.

Pharos 5 in 1 Woordeboeke, n.p., CD-ROM, Bowline Software, Kaapstad, Suid-Afrika.

Parry, A. \& Doan, R., 1994, Story re-visions: Narrative therapy in the postmodern world, The Guilford Press, New York, NY.

Prinsloo, K., 2011, Narratiewe Huwelikspastoraat-VBO-werkswinkel, ongepubliseerde klasaantekeninge, Universiteit van die Vrystaat, Bloemfontein op 14-15 Maart 2011.

The King's Speech, 2010, motion picture, The Weinstein Company, New York.

Weingarten, K., 2000, 'The discourse of daily life: intimacy and the politics of hope', paper presented at workshop of the Institute for Therapeutic Development, UNISA, Pretoria, 13 April.

White, M., \& Epston D, 1990, Narrative means to therapeutic ends, Dulwich Centre Publications, Adelaide, South Australia.

White, M., 1992, 'Deconstruction and therapy', Dulwich Center Newsletter 1, 27-38.

White, M., 1997, 'Narratives of therapists' lives', Experience, contradiction, narrative \& imagination: Selected papers of Michael White \& David Epston 1989-1991, South Australia, Adelaide, Dulwich Centre Publications.

White, M., 2007, Maps of Narrative Practice, W.W. Norton \& Company, New York, NY.

Zander, B. \& Zander, R.S., 2002, The art of possibility: Transforming Professional and Personal Life, Penguin Books, London. 